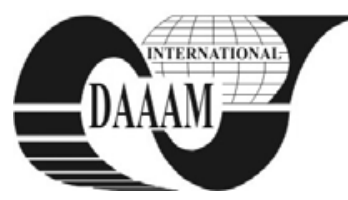

Annals of DAAAM for 2011 \& Proceedings of the 22nd International DAAAM Symposium, Volume 22, No. 1, ISSN $1726-9679$ ISBN 978-3-901509-83-4, Editor B. Katalinic, Published by DAAAM International, Vienna, Austria, EU, 2011 Make Harmony between Technology and Nature, and Your Mind will Fly Free as a Bird Annals \& Proceedings of DAAAM International 2011

\title{
E-GOVERNMENT - THE CASE OF ROMANIA
}

\section{POCORA, M[onica]; MIRONOV DURET, G[abriela] N[icoleta]; NECSULESCU, E[caterina]; PUSCA, F[lorentina]; DURET, N[icu] \& GOGA, G[ina] L[ivioara]}

\begin{abstract}
This paper presents the Romanian e-Government case, focusing on e-Government actors, infrastructure and the e-Government services for citizens and for businesses. The emergence of the global digital network - Internet, has generated a genuine digital revolution. As all revolutions, the digital revolution created uncertainty, discontinuity, but also opportunity. The opportunities introduced by Internet can be transformed into real benefits, and many sectors of the public and private life quickly adapted. In the globalized world, Internet has rapidly become a usual working instrument but also an indispensible aspect of everyday life. An increasing number of users consider Internet access to be an imperative condition to develop their activities. For some, life without Internet could be unimaginable. The new generation of eGovernment services will need to rely on and benefit from innovative technical approaches, such as clouds of public services and service-oriented architecture (SOA) to build open, flexible and collaborative eGovernment services while at the same time lowering ICT costs.
\end{abstract}

Key words: e-government, Romanian e-government websites, transparency, modern democracy

\section{INTRODUCTION}

E-Government is a response to the necessity of adapting government to modern democracy. E-Government increases the accessibility of each national government, making it available at any time, in any place, provided the user has an Internet connection. E-Government has its advantages but there is always place for further developments. As a European Union member state, Romania is dedicated to the achievement of its main objectives, among which being the priority to increase Internet services and make the most of the benefits offered by a single digital market. According to the UN e-government survey conducted in 2010, Romania ranks 47 out of 184 countries (United Nations E-Government Survey , 2010). The paper analyzes the strengths and weaknesses, the opportunities and the threats that e-Government is faced with in Romania. The Romanian legislative framework is also approached, being a necessity for the proper functioning of E-Government. The research methods used for this study are based on reviewing and analysis of existing research on the topic, including webbased documentation, usage statistics, press reports, reports from international organizations and national bodies and also reviewing of the national e-Government websites. This paper reports also on Internet usage in Romania, focusing on Internet usage by the population and also by the public and private sector. Furthermore, this paper analyses the development stage of e-Government in Romania, presenting steps made so far by this country. Transparency in government decision making and in its use of personal data help to build the trust of citizens and improve accountability of policy makers. Although many Member States have set transparency goals, no common European objectives exist yet.

\section{E-GOVERNMENT STATEMENT}

E-Government is classified into the following areas: Information (making information available online), communication (the ability to interactively access and exchange information), transaction (the actual carrying out of services, including the signing of application forms and electronic delivery of official documents and notifications) (The ABC guide of E-Government in Austria, 2008). We live in a society strongly influenced by technological changes and challenges and we are completely surrounded by technology. The digital lifestyle of the citizens is nowadays also embraced by public administrations and authorities which use information technologies in order to communicate in modern ways, to reach the citizens easily and thoroughly and to improve their overall functionality (Heichlinger, 2004 ).

The term of EGovernment has become a synonym for a modern state, it can be literally translated as "electronic government". However, the worldwide established meaning of eGovernment is "the administration of government by means of electronic technology" (Traunmuller, 2004).

Recent 2010 Eurostat statistics on EU 27 member states show that Romania has the lowest share of internet users who used the internet for finding information from public authorities' websites in the last 12 months, and also the lowest share of internet users who bought or ordered goods or services for private use over the internet in the last 12 months.

By 2015 European public administrations should be "recognised for being open, flexible and collaborative in their relations with citizens and businesses. They use eGovernment to increase their efficiency and effectiveness and to constantly improve public services in a way that caters for user's different needs and maximises public value, thus supporting the transition of Europe to a leading knowledge-based economy" (http://ec.europa.eu/information_society/activities/egovernment /library/index_en.htm.). Since eGovernment services are also of great importance for businesses, this Action Plan also aims that by $2015,80 \%$ of enterprises will have used eGovernment.

\section{E-GOVERNMENT ACTORS IN ROMANIA}

A unitary vision is had in view, with the purpose of developing a coherent and integrated national system for online public services devoted to its citizens and businesses. The Romanian Ministry of Communications and Information Society (MCSI) is the main eGovernment actor in Romania, subordinated to the Government and having the main role to accomplish the Government policy in the following areas: electronic communication, postal services, information technology, the services of information society and knowledgebased society (Romanian Ministry of Communications and Information Society, 2010). One of the main objectives of the Ministry of Communications and Information Society is to accomplish the service eRomania, along with its strategic component of eGovernment. The Strategic Plan has set the objective to give citizens, businesses, local and central 
administration the benefits of using a clear range of eGovernment services by the end of 2013.

MCSI has set the objective to create sustainable prerequisites in order to advance to an efficient Information Society. The Strategic Plan for 2010-2013 emphasizes the fact that eGovernment services are efficient methods of fighting corruption, can be considered as key-factors for institutional transparency and also for the reliable regulation of the business environment in Romania. Implementing eGovernment solutions can lead to important advantages such as reducing the necessary time for information dissemination, improving its quality, significantly reducing administrative costs.

The National Centre Digital Romania (CNRD) is a public institution subordinated to the Ministry of Communications and Information Society having the role to ensure the management of informational content and to information services from eRomania portal. CNRD has also the tasks of administration and operation of the systems that provide eGovernment services, minimizing the digital gap and maintaining the cooperation with national and international institutions in order to reach its objectives. CNRD will also have the task of implementation, operation and management of the Electronic "Point of single contact" provided for in the EU Services Directives (Directive 2006/123/EC of the European Parliament and of the Council of 12 December 2006 on services in the internal market). The Electronic "Point of single contact" is aimed at making public administration more efficient by creating an integrated market for services and by simplifying procedures applicable to service providers, with the overall purpose of creating an interoperable platform at national and European level.

Another actor of the eGovernment scenario in Romania is the National Centre of Management for the Information Society (CNMSI), which is coordinated by the Ministry of Communications and Information Society. CNMSI has launched an open proposal for local and central public authorities with the purpose of modernizing the infrastructure of Information and Communication Technology.

Through this approach, several advantages are being achieved: "zero" infrastructure costs for existing or future systems; unlimited scalability of hardware infrastructure; small costs of implementation and maintenance; the use of selfverification, self-healing technologies, that are characteristics of supercomputing. E-Romania is a strategy assumed by the Romanian Government for the purpose of creating 300 operational electronic services by the end of 2011. E-Romania has also the aim of obtaining a public institutional system that is interconnected, allowing citizens and the private sector to access public services in a direct and unlimited manner.

\section{STUDIES AND REPORTS ON E-GOVERNMENT IN ROMANIA}

From 2004, Romania obtained low scores in the egovernment rankings, generally due to the impediments presented by poor infrastructure, an often adverse business environment and limited skills development.

The Report analyzed eGovernment readiness in Romania according to the five-stages framework developed by the United Nations that views e-government as a multi-stakeholder interaction between government, businesses and the citizen:

Emerging presence means the information available is limited and basic. The government's online presence comprises a web page. Most information remains static with few interactive options for citizens.

Enhanced presence is the stage in which the government provides greater access to policy and legislative documents. Reports, newsletters and other types of content, are downloadable. The user can search for a document and help features including a site map are provided. Interaction is still primarily unidirectional with information flowing from the government to the citizen.
Interactive presence is the stage in which citizens can find downloadable forms for things like tax payments, or applications for license renewal. Audio and video capability is available for relevant public information. Contact details are online for government officials to be contacted via email, fax, telephone and post. The site is updated to keep the public up to date.

Transactional presence is the stage that allows two-way interaction between the citizen and government. It includes options such as paying taxes, applying for identity cards, birth certificates and passports, and renewing licenses online. Online payments are possible. Providers of goods and services are also able to bid online for public contracts via secure links.

Networked presence is the most advanced level in eGovernment development. The government encourages participatory decision making in a two-way dialogue. Interactive features such as an online comment form and other online consultation mechanisms enable the government to proactively solicit citizens' views on public policy and law making. In this stage the public sector agencies cooperate in a well-integrated and participatory manner.

\section{CONCLUSIONS}

E-Romania is a strategy assumed by the Romanian Government for the purpose of creating 300 operational electronic services by the end of 2011. E-Romania has also the aim of obtaining a public institutional system that is interconnected, allowing citizens and the private sector to access public services in a direct and unlimited manner.

E-Government allows information and communication technology to develop the quality and efficiency of public administration. Communication is made easier for citizens and businesses, costs are lowered and at the same time internal processes are sped up substantially. The quality and transparency of public services is raised considerably to everyone's benefit. A number of technical and legal preconditions need to be put in place to enable the implementation of the actions that will enhance eGovernment services in Europe. These include the promotion of interoperability across borders, which would allow - among others - sharing of information, deployments of one-stop-shop approaches, Europe wide use of (national) electronic identity solutions and payment schemes. Interoperability is supported through open specifications and the development of key enablers such as electronic identity management and stimulation of innovation in eGovernment.

\section{REFERENCES}

Heichlinger, A. ( 2004 ). eGovernment in Europe's Regions: Approaches and Progress in IST Strategy, Organisation and Services, and the Role of Regional Actors. Maastricht

Traunmuller, R. (2004). Electronic Government,. Springer Verlag, Lecture Notes in Computer Science

*** (2011) http://ec.europa.eu/information_society/activities/ egovernment/library/index_en.htm. (fără an). Preluat pe 2011

*** (2010) Romanian Ministry of Communications and Information Society. (2010). Preluat pe January 2011, de pe “The Strategic Plan for 2010-2013" [online]: http://www.mcsi.ro/Minister/Despre-MCSI/Misiune

*** (2008) The ABC guide of E-Government in Austria. (2008, July). Preluat pe January 2011, de pe bka.gv: http://www.bka.gv.at/DocView.axd?CobId=19394

*** (2010) United Nations E-Government Survey . (2010). Preluat pe January 2011, de pe Leveraging e-government at a time of financial and economic crisis, [online]: http://www2.unpan.org/egovkb/global_reports/10report.htm 